\title{
Influencing Factors of Behavior Intention and Actual Use of Technology: An Application of UTAUT Model on Science Undergraduates
}

\author{
Tanuja Khan \\ The Bhopal School of Social Sciences \\ Amit Kumar Nag \\ The Bhopal School of Social Sciences \\ Bharti Joshi \\ Devi AhilyaVishwavidhyalay \\ Rekha Acharya \\ Devi AhilyaVishwavidhyalay \\ Sheena Thomas \\ The Bhopal School of Social Sciences
}

This study was conducted by empirically testing a model to predict the factors affecting science undergraduates' behaviour intentions towards the actual use of technology (digital leaning). This study explored the behavioural intention of use of digital learning from the perspective of students by applying the extended UTAUT model. A cross-sectional study was conducted on science undergraduates. The data was derived from an online survey with 425 respondents and analyzed using a structural equation model. PLS-SEM was used for model and hypothesis testing. The result revealed that performance expectancy, effort expectancy, and social influence are positively associated with behaviour intention and actual use of technology. Facilitating conditions were negatively associated with BIUT (behavior intention and actual use of technology). Our findings correspond with the UTAUT model and provide a practical reference for educational institutions on designing digital learning for further studies.

Keywords: performance expectancy, effort expectancy, social influence, facilitating conditions, behavior intention and actual use of technology, UTAUT model, science undergraduates

\section{INTRODUCTION}

Acceptance analysis of technology was measured by various methods. TFA (technology future analysis) is one of them, which involves technology intelligence forecasting, technology road mapping, technology foresight, and technology assessment. Devis and Venkatesh defined perceived ease and usefulness in their studies (V Venkatesh et al., 2003). The Technology Acceptance Model is the best known 
and is repeatedly used in studies which focus on users. The theoretical model used in this study is the Unified Theory of Acceptance and Use of Technology by Venkatesh (V. Venkatesh et al., 2003). This model includes eight models regarding acceptance of technology.

\section{TABLE 1}

THEORETICAL MODEL AND ITS USES

\begin{tabular}{|l|l|}
\hline \multicolumn{1}{|c|}{ Model Details } & \multicolumn{1}{c|}{ Use } \\
\hline $\begin{array}{l}\text { Theory of Reasoned Action } \\
\text { (TRA) }\end{array}$ & $\begin{array}{l}\text { Behavioral intention is determined by the attitude towards } \\
\text { behavior and by the subjective norm in the close } \\
\text { environment(Fishbein \& Ajzen, 1975) }\end{array}$ \\
\hline Technology Acceptance Model & $\begin{array}{l}\text { It shows the influence of perceived usefulness and perceived ease } \\
\text { of use on the behavioral intention to use a technology and on the } \\
\text { attitude towards using it(Davis, 1993) }\end{array}$ \\
\hline $\begin{array}{l}\text { Motivational Model (MM; Davis, } \\
\text { Bagozzi, \& Warshaw, 1992) }\end{array}$ & $\begin{array}{l}\text { explains how extrinsic and intrinsic motivation can be used to } \\
\text { understand new technology acceptance and use }\end{array}$ \\
\hline $\begin{array}{l}\text { Theory of Planned Behavior } \\
\text { (TPB) }\end{array}$ & $\begin{array}{l}\text { perceived behavioral control this theory is the extended version of } \\
\text { the TRA(Ajzen, 1985) }\end{array}$ \\
\hline $\begin{array}{l}\text { Hybrid model, namely the } \\
\text { Combined TAM and TPB }\end{array}$ & $\begin{array}{l}\text { Job-fit, complexity of the innovation, long-term consequences, } \\
\text { affect towards use, social factors and facilitating } \\
\text { conditions(Viswanath Venkatesh et al., 2016). }\end{array}$ \\
\hline $\begin{array}{l}\text { Innovation Diffusion Theory } \\
\text { (IDT; Rogers, 1995) }\end{array}$ & $\begin{array}{l}\text { consists of five elements of innovation that influence the } \\
\text { acceptance behavior of an individual: relative advantage, ease of } \\
\text { use, image, visibility, compatibility, results demonstrability and } \\
\text { voluntariness of use }\end{array}$ \\
\hline $\begin{array}{l}\text { Social Cognitive Theory (SCT; } \\
\text { Bandura, 1986). }\end{array}$ & $\begin{array}{l}\text { The SCT suggests a reciprocal influence of environmental factors, } \\
\text { personal factors (self-efficacy, affect, anxiety etc.) and behavior. }\end{array}$ \\
\hline
\end{tabular}

A unified theory of acceptance and actual use of technology was developed by Venkatesh (V. Venkatesh et al., 2003). It will be used as a pre-foundation for the present study. Based on the eight models (table 1), which contain the most important constructs (Jr. et al., 2017). The UTAUT is predicted to explain about $53 \%$ of the variance in the acceptance and intention to use technology-related applications (ALBLOOSHI \& ABDUL HAMID, 2021). UTAUT has been used to understand the user's engagement with particular technologies across the teaching and learning process, with particular reference to the science stream (Momani, 2020).

UTAUT proposed four major factors such as performance expectancy, effort expectancy, social influence, and facilitation conditions as a predictors of behavior intention and actual use of technology. The reason behind choosing the science undergraduates is that the science stream has all the practical and application-based subjects. It seems too difficult to accept technology in their learning style (Viswanath Venkatesh et al., 2016). The UTAUT model is taken as the theoretical basis of this study due to its empirical validity in the scientific field. These constructs are also moderated by gender, age, and different streams within the science discipline, like engineering, medical, pure sciences, and mathematics, etc.

According to Venkatesh et al. (2003), performance expectancy is when the user believes that the use of technology would enable learners to accomplish a specific learning performance. Performance expectancy is perceived usefulness in the technology acceptance model (V. Venkatesh et al., 2003). With the use of technology, application would be easy to understand. This kind of understanding is known as effort expectancy, and it is also similar to the perceived ease of use in the TAM Model (Scherer et al., 2019). The term "social influence" refers to the situation in which a user chooses a technology based on the influence of family, peers, friends, and other important people in society (Ganotice\& King, 2014).Technology based 
on available resources like teachers, the internet, devices, and other available infrastructure are anticipated as facilitation conditions (Kalule et al., 2019). The UTAUT is illustrated in figure 1.

\section{FIGURE 1 \\ UNIFIED THEORY OF ACCEPTANCE AND USE OF TECHNOLOGY}

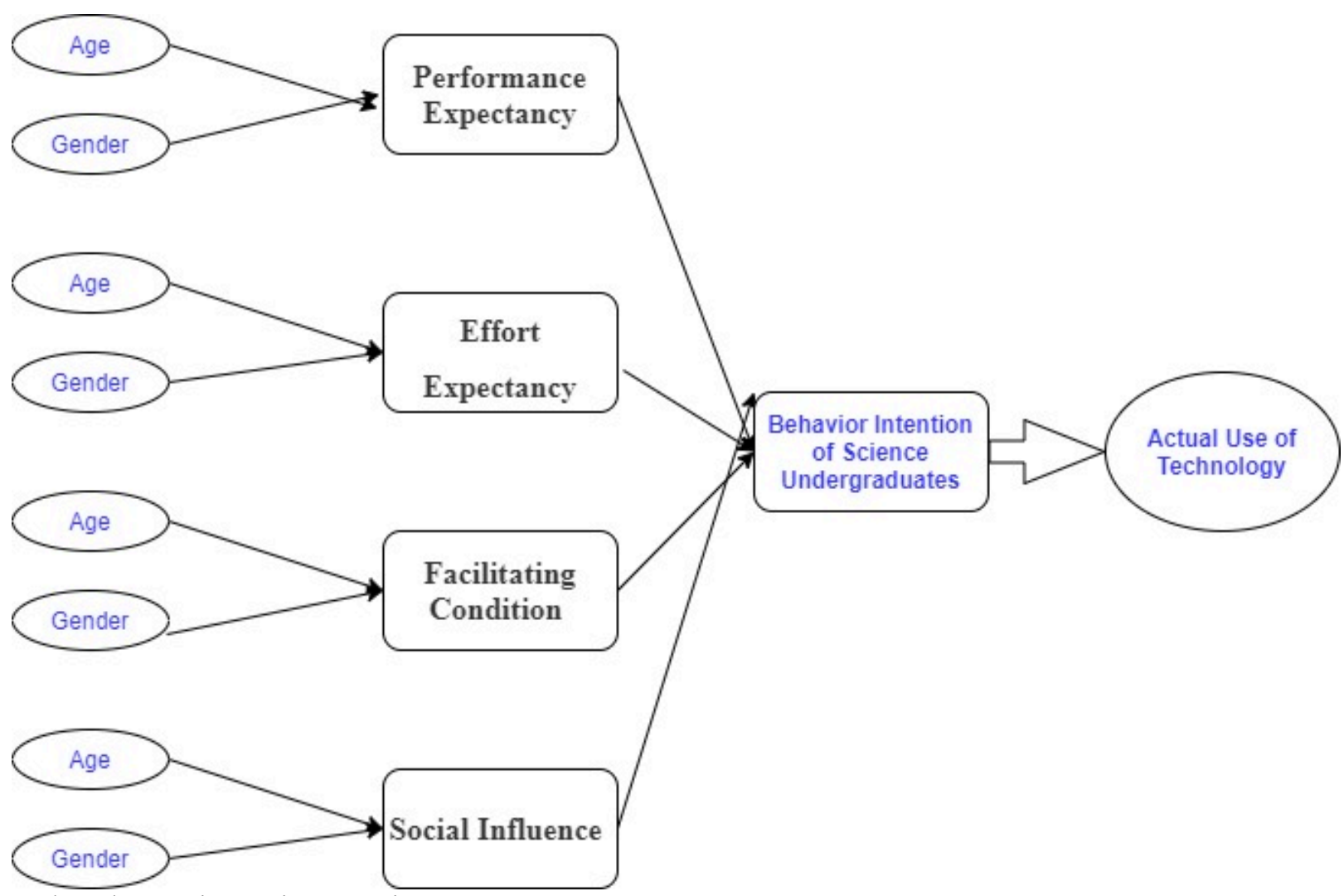

Venkatesh, Morris, Davis, \& Davis, 2003

With particular reference to the science stream, UTAUT has been used to understand the user's engagement with particular technologies across the teaching and learning process. The UTAUT model is taken as the theoretical basis of this study due to its empirical validity in the scientific field.

Performance expectancy (PE) can be defined as "the degree to which the user expects that using the system will help him or her to attain gains in job performance". Research suggests that this is one of the most important predictors of the intention to use technology. The relationship between performance expectancy and behavioural intention was proven to be moderated by gender and age, meaning that the effect of the predictor is stronger for younger people and men. Subsequently, effort expectancy (EE) can be explained as the anticipated complexity of the technology and the degree of energy needed to use it. The effect of effort expectancy on behavioural intention was moderated by gender, age and experience. The effect was more significant for women, older people and less experienced workers (Venkatesh et al., 2003). Social influence (SI) refers to the belief of important others that the individual should accept the new system. The impact of this factor has the tendency to be more important among women, older people and lower levels of experience. In the context of non-voluntary use, the impact of social influence is also bigger (Venkatesh et al., 2003). Finally, the facilitating conditions (FC) cover the extent to which an individual perceives that infrastructure can be used to apply the new technology. The expected moderation of age and experience was found. The effect of facilitating conditions on actual use was stronger for older workers and people with higher levels of experience (Venkatesh et al., 2003). This study focuses on the effect of performance expectancy, effort expectancy and social influence on the behavioural intention to use non- 
fluoroscopy-guided positioning. The direct effect of facilitating conditions on the actual use of non-FGP is not included in this study, because it aimsto gain a deeper understanding of the factors influencing behavioural intention. The two outcome variables in the UTAUT are behavioural intention and the actual use. Behavioral intention refers to a desire or a purpose and is a direct determinant of the actual use. Whereas the intention to use a system can change over time, the behaviour is the actual form of usage argued in their TRA that beliefs influence attitudes, and those in turn create intentions. The relationship between both constructs is found to be conclusive in the context of healthcare.

\section{BACKGROUND OF THE STUDY}

With the unexpected switching to online classes due to the corona virus outbreak. This sudden switch to online learning has left some students confused about some course requirements for the rest of the semester. Learners faced lots of challenges, especially in science, as during the initial face of digital learning, teachers only knew how to deliver the lectures verbally, but for the science stream, learning needed more interaction and also writing work (Mathematics, Statistics, Physics, Chemistry, etc). Sciences should be learned through mind-on and hands-on activities. Therefore, teachers must be able to create virtual classroom conditions that help students maintain learning momentum while they cannot interact with each other physically. Keeping all these in mind, researchers conducted the present study to know the science undergraduates' behavior, intention and actual use of the digital learning system with the help of the UTAUT model. The aim of this study is to gain knowledge about the acceptance of digital learning systems among science undergraduate students, particularly those from the science undergraduate institutes of Bhopal city. The data used to conduct this study was gathered by another researcher. The effect of performance expectancy, effort expectancy and social influence on the behavioural intention to use digital learning systems during the new normal will be explored. Furthermore, the possible influence of individualised consideration on these effects will be examined.

The background characteristics that were analyzed included the gender and age of the respondent. The descriptive analysis is below for the present study.

TABLE 2

\section{FREQUENCIES OF GENDER}

\begin{tabular}{|l|c|c|c|}
\hline \multicolumn{1}{|c|}{ Levels } & Counts & \% Of Total & Cumulative \% \\
\hline Female & 266 & $62.6 \%$ & $62.6 \%$ \\
\hline Male & 154 & $36.2 \%$ & $98.8 \%$ \\
\hline Not to prefer & 5 & $1.2 \%$ & $100.0 \%$ \\
\hline
\end{tabular}

Results in Table 2 show the respondents in the gender category of females are $62.6 \%$ and males are $36.2 \%$, where $1.2 \%$ were in the category of not preferred.

TABLE 3 FREQUENCIES OF AGE

\begin{tabular}{|l|c|c|c|}
\hline \multicolumn{1}{|c|}{ Levels } & Counts & \% of Total & Cumulative \% \\
\hline Below 18 Years & 10 & $2.4 \%$ & $2.4 \%$ \\
\hline 18-20 Years & 223 & $52.5 \%$ & $54.8 \%$ \\
\hline Above 20 Years & 192 & $45.2 \%$ & $100.0 \%$ \\
\hline
\end{tabular}

Results in Table 3 show that respondents in the age category below 18 years contributed $2.4 \%$. This was followed by the group of $18-20$ years with a frequency of $52.5 \%$, also followed by the category above 20 years at $45.2 \%$. 
TABLE 4

DESCRIPTIVE ANALYSIS FOR PERFORMANCE EXPECTANCY FOR DIGITAL LEARNING SYSTEM

\begin{tabular}{|l|c|c|c|c|}
\hline & PE1 & PE2 & PE3 & PE4 \\
\hline N & 425 & 425 & 425 & 425 \\
\hline Missing & 0 & 0 & 0 & 0 \\
\hline Mean & 3.91 & 3.71 & 3.94 & 3.65 \\
\hline Median & 4 & 4 & 4 & 4 \\
\hline Standard deviation & 1.05 & 1.12 & 1.05 & 1.21 \\
\hline Variance & 1.1 & 1.25 & 1.11 & 1.46 \\
\hline Range & 4 & 4 & 4 & 4 \\
\hline Minimum & 1 & 1 & 1 & 1 \\
\hline Maximum & 5 & 5 & 5 & 5 \\
\hline Skewness & -1.05 & -0.735 & -1.09 & -0.694 \\
\hline Std. error skewness & 0.118 & 0.118 & 0.118 & 0.118 \\
\hline Kurtosis & 0.748 & -0.176 & 0.884 & -0.432 \\
\hline Std. error kurtosis & 0.236 & 0.236 & 0.236 & 0.236 \\
\hline
\end{tabular}

Findings in Table 4 show that there are positive perceptions of performance expectancy in regards to PE1 (Mean=3.91), PE2 (Mean=3.71), PE3 (Mean=3.94), and PE4 (Mean=3.65). All the means are near to 4 and above 3.5, an indication that performance expectancy influences the adoption and use of digital education.

TABLE 5

DESCRIPTIVE ANALYSIS FOR EFFORT EXPECTANCY FOR DIGITAL LEARNING SYSTEM

\begin{tabular}{|l|c|c|c|}
\hline & EE1 & EE2 & EE3 \\
\hline N & 425 & 425 & 425 \\
\hline Missing & 0 & 0 & 0 \\
\hline Mean & 3.91 & 3.8 & 3.82 \\
\hline Median & 4 & 4 & 4 \\
\hline Standard deviation & 0.986 & 1.05 & 1.09 \\
\hline Variance & 0.973 & 1.11 & 1.18 \\
\hline Range & 4 & 4 & 4 \\
\hline Minimum & 1 & 1 & 1 \\
\hline Maximum & 5 & 5 & -0.904 \\
\hline Skewness & -0.916 & -0.829 & 0.118 \\
\hline Std. error skewness & 0.118 & 0.118 & 0.344 \\
\hline Kurtosis & 0.615 & 0.375 & 0.236 \\
\hline Std. error kurtosis & 0.236 & 0.236 & \\
\hline
\end{tabular}

Findings in Table 5 show that there are positive perceptions of effort expectancy in regards to EE1 (Mean=3.91), EE2 (Mean=3.79), and EE4 (Mean=3.82). All the means are near to 4 and above 3.5, an indication that effort expectancy influences the adoption and use of digital education. 
TABLE 6

DESCRIPTIVE ANALYSIS FOR SOCIAL INFLUENCE FOR DIGITAL LEARNING SYSTEM

\begin{tabular}{|l|c|c|c|}
\hline & SI1 & SI2 & SI3 \\
\hline $\mathbf{N}$ & 425 & 425 & 425 \\
\hline Missing & 0 & 0 & 0 \\
\hline Mean & 3.73 & 3.73 & 4.75 \\
\hline Median & 4 & 4 & 1.03 \\
\hline Standard deviation & 1.01 & 1 & 1.06 \\
\hline Variance & 1.03 & 1 & 4 \\
\hline Range & 4 & 4 & 1 \\
\hline Minimum & 1 & 1 & 5 \\
\hline Maximum & 5 & 5 & -0.711 \\
\hline Skewness & -0.611 & -0.659 & 0.118 \\
\hline Std. error skewness & 0.118 & 0.118 & 0.112 \\
\hline Kurtosis & -0.0735 & 0.159 & 0.236 \\
\hline Std. error kurtosis & 0.236 & 0.236 & \\
\hline
\end{tabular}

Findings in Table 6 show that there are positive perceptions of social influence with regards to SE1 (Mean=3.72), SE2 (Mean=3.73), and SE4 (Mean=3.74). All the means are near to 4 and above 3.5, an indication that effort expectancy influences the adoption and use of digital education.

TABLE 7

\section{DESCRIPTIVE ANALYSIS FOR FACILITATING CONDITIONS FOR DIGITAL LEARNING SYSTEM}

\begin{tabular}{|l|c|c|c|}
\hline & FC1 & FC2 & FC3 \\
\hline $\mathbf{N}$ & 425 & 425 & 425 \\
\hline Missing & 0 & 0 & 0 \\
\hline Mean & 4.04 & 4.12 & 4 \\
\hline Median & 4 & 4 & 1.02 \\
\hline Standard deviation & 0.862 & 0.799 & 1.04 \\
\hline Variance & 0.744 & 0.639 & 4 \\
\hline Range & 4 & 4 & 1 \\
\hline Minimum & 1 & 1 & 5 \\
\hline Maximum & 5 & 5 & -0.881 \\
\hline Skewness & -1.03 & -1.11 & 0.118 \\
\hline Std. error skewness & 0.118 & 0.118 & 0.505 \\
\hline Kurtosis & 1.47 & 2.23 & 0.236 \\
\hline Std. error kurtosis & 0.236 & 0.236 & \\
\hline
\end{tabular}

Findings in Table 7 show that there are positive perceptions of facilitating conditions in regards to FC1 (Mean=4.03), FC2 (Mean=4.12), and FC4 (Mean=3.84). All the means are 4 and above 3.5, an indication that effort facilitates conditions for the adoption and use of digital education. 
TABLE 8

DESCRIPTIVE ANALYSIS FOR BEHAVIORAL INTENTION FOR DIGITAL LEARNING SYSTEM

\begin{tabular}{|l|c|c|c|c|}
\hline & BIAU1 & BIAU2 & BIAU3 & BIAU4 \\
\hline N & 425 & 425 & 425 & 425 \\
\hline Missing & 0 & 0 & 0 & 0 \\
\hline Mean & 3.85 & 3.75 & 3.68 & 3.76 \\
\hline Median & 4 & 4 & 4 & 4 \\
\hline Standard deviation & 1.07 & 1.08 & 1.13 & 1.11 \\
\hline Variance & 1.14 & 1.17 & 1.28 & 1.23 \\
\hline Range & 4 & 4 & 4 & 4 \\
\hline Minimum & 1 & 1 & 1 & 1 \\
\hline Maximum & 5 & 5 & 5 & 5 \\
\hline Skewness & -0.931 & -0.83 & -0.693 & -0.835 \\
\hline Std. error skewness & 0.118 & 0.118 & 0.118 & 0.118 \\
\hline Kurtosis & 0.452 & 0.218 & -0.206 & 0.0888 \\
\hline Std. error kurtosis & 0.236 & 0.236 & 0.236 & 0.236 \\
\hline
\end{tabular}

Findings in Table 8 show that there are positive perceptions of behavioural intention and actual use in regards to BIAU1 (Mean=3.84), BI2 (Mean=3.75), BIAU3 (Mean=3.68) and BIAU4 (Mean=3.75). All the means are 4 and above 4 , an indication that performance expectancy influences the adoption and use of digital education.

\section{CONCEPTUAL FRAMEWORK}

Covid-19 has considerably modified the human outlook forever, particularly the education system, and learners' moon-faced scores of challenges thanks to sharp modifications within the education system, from face-to-face to digital systems. Science is the subject that needs additional interaction and writing work. Acceptance of a digital learning system for the science education world is in an exceedingly perplexing situation, although the government and academic establishments have tried loads to beat these challenges. Keeping these parameters in mind, the planned framework has been conceptualised (figure 2). From the learners' purpose, performance expectancy, Effort Expectancy, Facilitating Conditions, Social Influence and behaviour intention and actual use were thought of. 
FIGURE 2

\section{CONCEPTUAL FRAMEWORK}

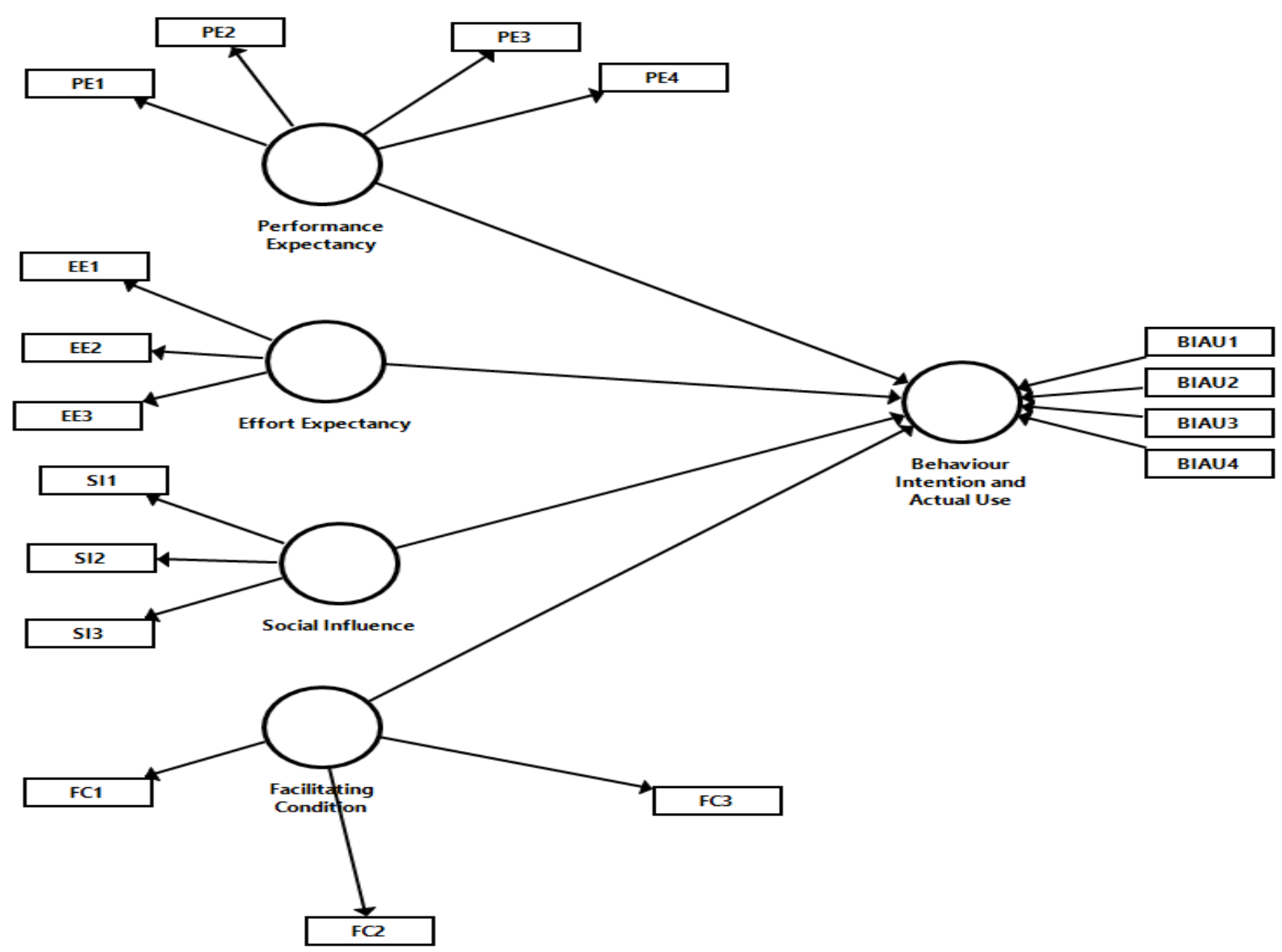

The analysis model for this study is outlined in figure 3. Performance expectancy, effort expectancy, facilitating conditions, and social influence are the independent variables. The dependent variables were behaviorintention, and actual use of technology. 


\section{FIGURE 3 \\ RESEARCH MODEL}

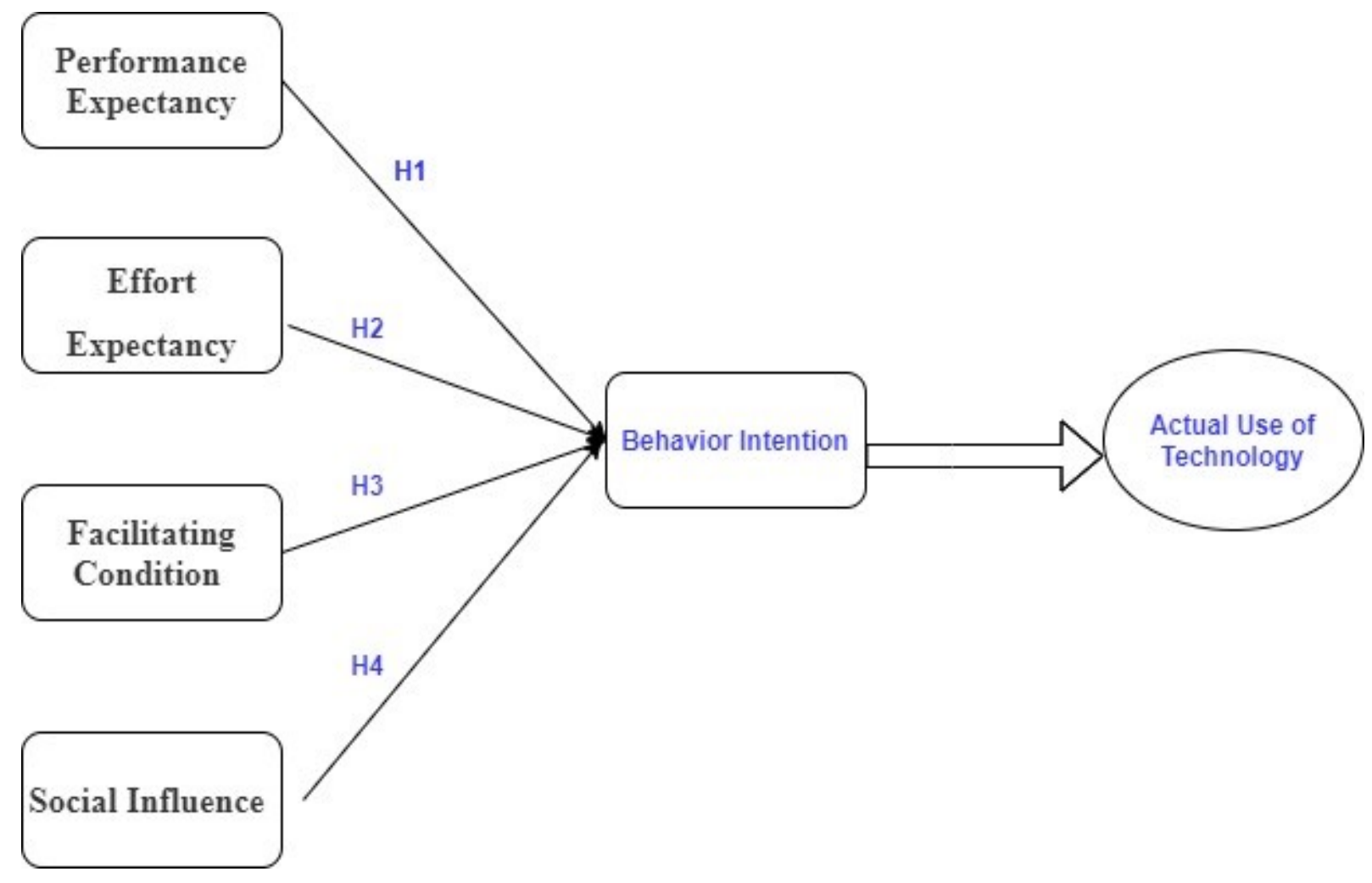

\section{RESEARCH HYPOTHESES DEVELOPMENT}

This study can commit to exploring the subsequent analysis hypotheses supported by the analysis model illustrated in figure 2. Performance expectancy, in step with Venkatesh et al. (2003), is the perception of the utilization of a specific technology that can assist or change him or her to accomplish a selected task performance. It's been established that performance expectancy could be a determinant of the behaviour intention of using technology-related applications. The individual's perception that the utilisation of elearning with references to the science stream can give some advantages might influence the behaviour intention to actually use technology. In terms of activity intention to actually use technology, studies have shown that performance expectancy includes a vital positive impact on the behaviour intention to use technology. The trouble with expectancy is that it is the extent to which a user believes that the utilization of a specific technology will be freed from challenges and can be simple to use. Effort expectancy has an influence on the user acceptance of recent technology. Previous studies have shown that effort expectancy could be a robust predictor of a behavior's intention to actually use technology. Facilitating conditions is the perception of the utilization that there's the provision of adequate technical and structural infrastructure to alter the use of a selected technology. The acceptance of a technology is influenced by facilitating conditions.Studies have indicated that facilitating conditions have a vital positive influence on behaviour intentions, i.e., whether they actually use technology. Social influence is the extent to which the perceptions and opinions of friends, family, and important personalities do impact the user's views toward the adoption of a selected technology. The communications from friends and family concerning the behaviour and intention to actually use technology will either discourage or encourage the adoption of technology. Social influence has been found to be a significant predictor of behaviour intention to use technology. 
Hypothesis 1 (H1): Performance expectancy has a positive influence on the behavioral intention to actual use technology.

Hypothesis 2 (H2): Effort expectancy has a positive influence on the behavioral intention to actual use technology.

Hypothesis 3 (H3): Facilitating conditions has a positive influence on the behavioral intention to actual use technology.

Hypothesis 4 (H4): Social influence has a positive influence on the behavioral intention to actual use technology.

A cross-sectional field survey research design was adopted and, thus, quantitative research techniques were used during data collection. A cross-sectional field survey research design was used, given that researchers are able to collect data on beliefs, practises or situations from a random sample of subjects in the field using survey questionnaires (Bhattacherjee, 2012). Questionnaires used were tested for reliability and validity before the survey with the help of SEM (Structural Equation Model) software.

The propositions of the UTAUT model have been severally tested in western and developed nations' contexts. However, there are inadequate empirical validations of the propositions of the UTAUT model in a non-western context as well as in countries categorised as developing nations. Hence, the purpose of this study was to examine the direct and indirect effects of the four determinants of technology adoption on students' behavioural intentions and the actual use of technology of science undergraduates in the Bhopal city. The variables for this study were adapted from previous studies. Performance expectancy, effort expectancy, facilitating conditions, social influence, and the behavioural intention to use were adopted. As the new normal during this pandemic is all about digital learning, the population for the present study is very large. Due to the large size of the population and limited financial, human, and time-resource resources, this study was not able to cover all the science educational institutes but only used accessible populations. In this study, learners are from Science Educational Institutes from Bhopal City only. The instrument was then administered to 500 potential respondents who were science undergraduates. A total of 425 questionnaire instruments were returned to digital learning users (respondents) who were from the Bhopal district, which accounts for $85 \%$ of the questionnaires administered. The analysis was done with SEM Software. The study used descriptive as well as inferential statistics.

The questionnaire consisted of 21 items meant to collect information about demographics (04 items) and the research variables (17 items): performance expectancy, effort expectancy, social influence, behavioural intention, and actual use of the digital learning system. The questionnaire was divided into two sections. The first section contained questions about demographic variables and other personal information. The second section contained questions about the constructs included in the research. Constructs were measured on a five-point Likert scale. The instruments were measured on a 5-point Likert-type scale ranging from $1=$ strongly disagree to $5=$ strongly agree. Each of the variables contained different unique questions. The questionnaire instruments were pre-tested and piloted to have clarity and anticipated challenges eliminated before the actual instrument administration. Pretesting and piloting contribute to achieving acceptable validity and reliability, removing ambiguities and unclear statements or questions, and finally, adding value and credibility to the entire research process. The constructive feedback received from the pretesting and piloting was instrumental in revising some portions of the instrument.

A Structural Equation Model is used to check the validity and reliability of the self-reported questionnaire. A questionnaire was developed with a five-point Likert scale of Strongly Agree, Agree, Neutral, Disagree and Strongly. The questionnaire items were analyzed using SmartPLS SEM software. The following are the values for reliability and validity as shown in Table 9. 


\section{CONVERGENT VALIDITY AND RELIABILITY}

Convergent validity is the degree to which the indicators of a specific construct converge or share a high proportion of the variance for that construct (Jr. et al., 2017). In other words, it refers to the level by which a measure positively relates to other measures within the same construct, i.e. the degree to which a latent construct explains the variance of its indicators. According to Hair et al. (2014), convergent validity can be assessed using the factor loadings, composite reliability (CR) and the Average Variance Extracted (AVE). To achieve convergent validity, each construct should have an AVE of $\geq 0.50$, and the factor loadings should be preferably greater than 0.70. Although Byrne (2013) suggests that factor loadings of 0.50 are acceptable if the summations of the loadings result in high loading scores contributing to AVE scores of 0.50 or greater, Table 9 shows the factor loadings and AVE of each of the constructs in the study. All measured constructs had AVE scores greater than the threshold value of 0.50 and factor loadings ranging from 0.694 to 0.888 consecutively, indicating that convergent validity had been established (Byrne, 2013 and Gefen, Straub \& Boudreau, 2000).

TABLE 9

CONSTRUCT RELIABILITY AND VALIDITY

\begin{tabular}{|c|c|c|c|c|c|c|}
\hline Construct & Items & Loadings & $\begin{array}{l}\text { Outer } \\
\text { Weight }\end{array}$ & $\begin{array}{l}\text { Cronbach's } \\
\text { Alpha }\end{array}$ & $\begin{array}{l}\text { Composite } \\
\text { Reliability }\end{array}$ & $\begin{array}{l}\text { Average } \\
\text { Variance } \\
\text { Extracted } \\
\text { (AVE) }\end{array}$ \\
\hline \multirow{4}{*}{$\begin{array}{l}\text { Behavioral } \\
\text { Intention \& } \\
\text { Actual Use of } \\
\text { Technology }\end{array}$} & BIUT1 & 0.92 & 0.243 & \multirow{4}{*}{0.942} & \multirow{4}{*}{0.959} & \multirow{4}{*}{0.853} \\
\hline & BIUT2 & 0.935 & 0.13 & & & \\
\hline & BIUT3 & 0.964 & 0.43 & & & \\
\hline & BIUT4 & 0.943 & 0.256 & & & \\
\hline \multirow{3}{*}{$\begin{array}{l}\text { Effort } \\
\text { Expectancy }\end{array}$} & EE1 & 0.855 & 0.326 & \multirow{3}{*}{0.782} & \multirow{3}{*}{0.872} & \multirow{3}{*}{0.694} \\
\hline & EE2 & 0.913 & 0.386 & & & \\
\hline & EE3 & 0.924 & 0.4 & & & \\
\hline \multirow{3}{*}{$\begin{array}{l}\text { Facilitating } \\
\text { Conditions }\end{array}$} & $\mathrm{FC} 1$ & 0.879 & 0.373 & \multirow{3}{*}{0.838} & \multirow{3}{*}{0.902} & \multirow{3}{*}{0.755} \\
\hline & $\mathrm{FC} 2$ & 0.893 & 0.367 & & & \\
\hline & FC3 & 0.849 & 0.405 & & & \\
\hline \multirow{4}{*}{$\begin{array}{l}\text { Performance } \\
\text { Expectancy }\end{array}$} & PE1 & 0.892 & 0.289 & \multirow{4}{*}{0.778} & \multirow{4}{*}{0.857} & \multirow{4}{*}{0.6} \\
\hline & PE2 & 0.89 & 0.27 & & & \\
\hline & PE3 & 0.878 & 0.279 & & & \\
\hline & PE4 & 0.898 & 0.287 & & & \\
\hline \multirow{3}{*}{$\begin{array}{l}\text { Social } \\
\text { Influence }\end{array}$} & SI1 & 0.944 & 0.338 & \multirow{3}{*}{0.937} & \multirow{3}{*}{0.96} & \multirow{3}{*}{0.888} \\
\hline & $\mathrm{SI} 2$ & 0.958 & 0.356 & & & \\
\hline & SI3 & 0.948 & 0.359 & & & \\
\hline
\end{tabular}

Reliability is the extent to which an instrument is free from random errors and the extent to which such an instrument produces consistent results if repeated in other settings or contexts (David \& Sutton, 2011; Pallant, 2011b). This implies that reliability and error are related, in the sense that the higher the error, the less reliable an instrument is and vice versa. In this study, the internal consistency reliability test and composite reliability were used to determine the reliability of the scales. Table 9 shows the composite reliability scores and Cronbach alpha values for each of the measured variables. All constructs had 
composite reliability ranging from 0.840 to 0.960 and Cronbach alpha values ranging from 0.778 to 0.942 , respectively.

\section{DISCRIMINANT VALIDITY}

The Fornell-Larcker Criterion (1981) was applied to investigate discriminant validity. The FornellLarcker Criterion helps to evaluate the degree of shared variance that exists between the latent variables.

TABLE 10

DISCRIMINANT VALIDITY

\begin{tabular}{|l|c|c|c|c|c|}
\hline & $\begin{array}{c}\text { Behaviour } \\
\text { Intention and } \\
\text { Actual Use }\end{array}$ & $\begin{array}{c}\text { Effort } \\
\text { Expectancy }\end{array}$ & $\begin{array}{c}\text { Facilitating } \\
\text { Condition }\end{array}$ & $\begin{array}{c}\text { Performance } \\
\text { Expectancy }\end{array}$ & $\begin{array}{c}\text { Social } \\
\text { Influence }\end{array}$ \\
\hline $\begin{array}{l}\text { Behaviour Intention } \\
\text { and Actual Use }\end{array}$ & & & & & \\
\hline Effort Expectancy & $\mathbf{0 . 8 2 1}$ & $\mathbf{0 . 8 9 8}$ & & & \\
\hline $\begin{array}{l}\text { Facilitating } \\
\text { Condition }\end{array}$ & 0.673 & 0.755 & $\mathbf{0 . 8 7 4}$ & & \\
\hline $\begin{array}{l}\text { Performance } \\
\text { Expectancy }\end{array}$ & 0.833 & 0.817 & 0.627 & $\mathbf{0 . 8 8 9}$ & \\
\hline Social Influence & 0.815 & 0.792 & 0.681 & 0.813 & $\mathbf{0 . 9 5 0}$ \\
\hline
\end{tabular}

Figures in bold represent the Square Root of Average Variance Extracted (AVE) and indicate discriminant validity. The other figures are correlation coefficients. The results of table 10 indicate that the square root of the average variance extracted (AVE) was higher than that of all crossed construct correlation values, indicating that the study is fit for conduction of final analysis.

TABLE 11

MODEL FIT

\begin{tabular}{|l|c|c|}
\hline & Saturated Model & Estimated Model \\
\hline SRMR & 0.042 & 0.042 \\
\hline d_ULS & 0.272 & 0.272 \\
\hline d_G & 0.257 & 0.257 \\
\hline Chi-Square & 655.150 & 655.150 \\
\hline NFI & 0.917 & 0.917 \\
\hline
\end{tabular}

All the values shown in table 11 are above the threshold values, so it is proved that the above analysis shows the model for the research is absolutely suitable for the present study.

A Structural Equation Model was employed in order to establish a relationship between the constructs and their prognostic significance. The bootstrapping process was employed with 500 bootstraps without changing the sign. This process helped in the identification of p-values for the framed hypotheses of the present study. 
FIGURE 4

RESEARCH STRUCTURAL MODEL

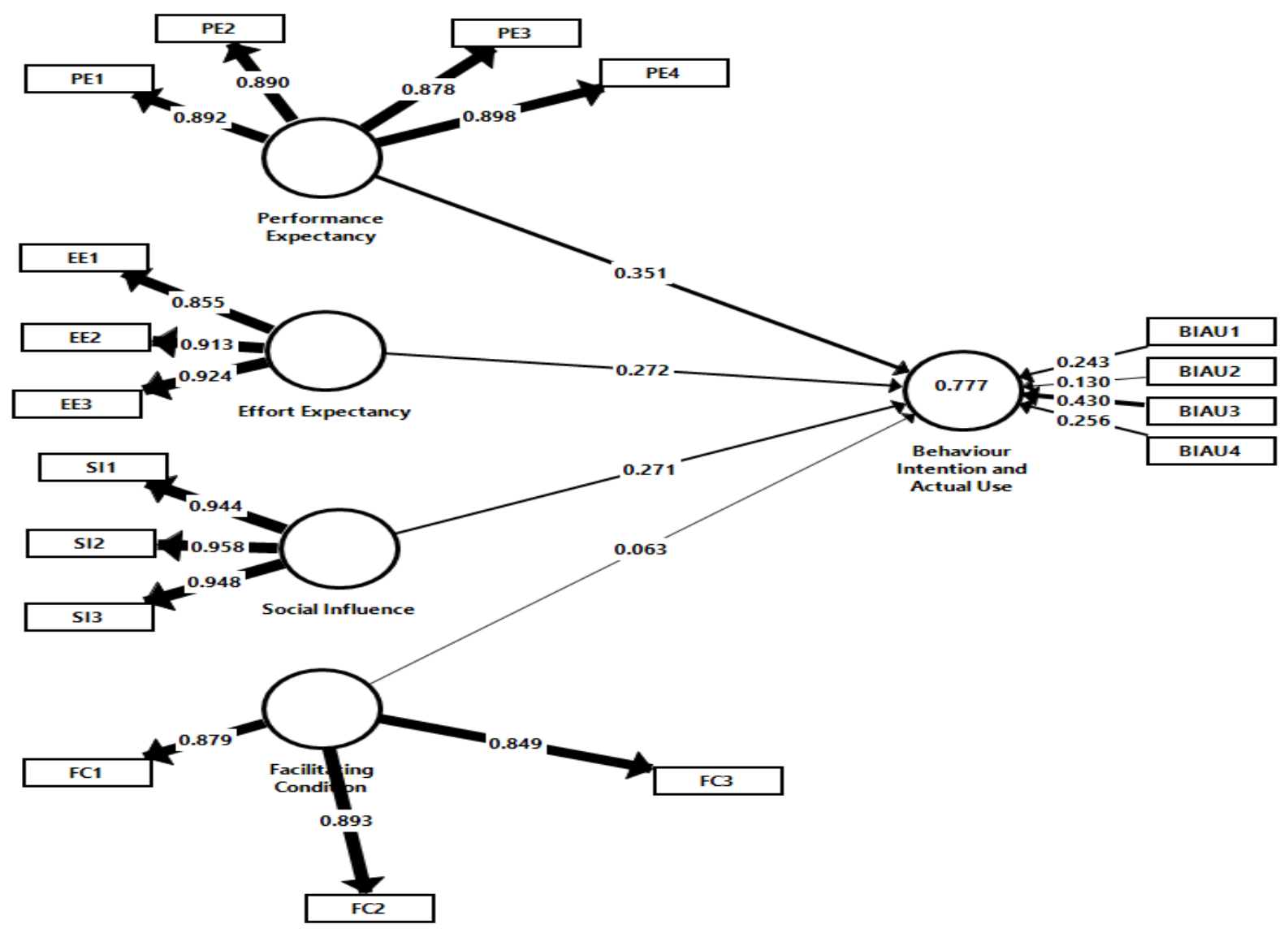

TABLE 12

SIGNIFICANCE TEST FOR THE STRUCTURAL MODEL PATH COEFFICIENT, T-VALUE AND P-VALUES

\begin{tabular}{|l|c|c|c|c|c|c|}
\hline \multicolumn{1}{|c|}{$\begin{array}{c}\text { Construct } \\
\text { Connection }\end{array}$} & $\begin{array}{c}\text { Original } \\
\text { Sample } \\
\text { (O) }\end{array}$ & $\begin{array}{c}\text { Sample } \\
\text { Mean (M) }\end{array}$ & $\begin{array}{c}\text { Standard } \\
\text { Deviation } \\
\text { (STDEV) }\end{array}$ & $\begin{array}{c}\text { T } \\
\text { Statistics } \\
\text { (|O/STDE } \\
\text { V|) }\end{array}$ & $\begin{array}{c}\text { P } \\
\text { Values }\end{array}$ & $\begin{array}{c}\text { Hypothesis } \\
\text { Supported }\end{array}$ \\
\hline $\begin{array}{l}\text { Effort Expectancy - } \\
\text { >Behaviour Intention } \\
\text { and Actual Use of } \\
\text { Tecchnology }\end{array}$ & 0.272 & 0.270 & 0.070 & 3.872 & 0.000 & Yes \\
\hline $\begin{array}{l}\text { Facilitating Condition } \\
\text {->Behaviour Intention } \\
\text { and Actual Use of } \\
\text { Tecchnology }\end{array}$ & 0.063 & 0.067 & 0.051 & 1.247 & 0.213 & No \\
\hline $\begin{array}{l}\text { Performance } \\
\text { Expectancy - } \\
\text { >Behaviour Intention } \\
\text { and Actual Use of } \\
\text { Tecchnology }\end{array}$ & 0.351 & 0.352 & 0.061 & 5.758 & 0.000 & Yes \\
\hline
\end{tabular}




\begin{tabular}{|c|c|c|c|c|c|c|}
\hline $\begin{array}{l}\text { Construct } \\
\text { Connection }\end{array}$ & $\begin{array}{l}\text { Original } \\
\text { Sample } \\
\text { (O) }\end{array}$ & $\begin{array}{c}\text { Sample } \\
\text { Mean (M) }\end{array}$ & $\begin{array}{l}\text { Standard } \\
\text { Deviation } \\
\text { (STDEV) }\end{array}$ & $\begin{array}{c}\text { T } \\
\text { Statistics } \\
(\mid \mathbf{O} / \text { STDE } \\
\text { V|) }\end{array}$ & $\begin{array}{c}\mathbf{P} \\
\text { Values }\end{array}$ & $\begin{array}{l}\text { Hypothesis } \\
\text { Supported }\end{array}$ \\
\hline $\begin{array}{l}\text { Social Influence - } \\
>\text { Behaviour Intention } \\
\text { and Actual Use of } \\
\text { Tecchnology }\end{array}$ & 0.271 & 0.269 & 0.063 & 4.269 & 0.000 & Yes \\
\hline
\end{tabular}

From Table 12, it can be seen that the direct path coefficients were all significant with t-values exceeding the critical value of 1.96 and p-values less than 0.05 (except FC > BIUT). Three of the direct effects had a strong positive relationship with the exception of the relationship between facilitating conditions and the behaviour intention \& actual use of e-learning, which had a negative relationship. This may be due to the exclusion of the moderating variables, age and gender, from the original UTAUT model in this study.

\section{DISCUSSION}

The purpose of this study was to identify factors that affect the science undergraduates' use of digital learning. This study's Research Model incorporates performance expectancy, effort expectancy, social influence, facilitating conditions, and predicted behaviour intention.PE, EE, and SI satisfied the factors most influencing behaviour intention and actual use of technology. In this study, all the participants are from the science stream. Many students have IT subjects in schools, so technology continues to evolve. Students learn not through the sudden outburst of technology, but yes, they release the importance of technology and accept it. In the contemporary world, technology and digital learning are relatively accessible, thereby providing a favourable learning environment for their behaviour and actual use of technology. The findings of the study confirmed that PE and EE and SI had significantly positive effects on BI and AUT. In addition, the results of our analysis highlighted the fundamental role of performance expectancy. Effort expectancy is also positively associated with the satisfaction of actual use of technology. Based on the findings of the present study, digital learning by science undergraduates is an increasingly important method of learning for science undergraduates. Therefore, regarding the future development of digital learning, educational institutes are recommended to provide subject-wise customized online forums for learners.

This study had several limitations that could be addressed in future studies. First, the results were based on only science undergraduates, and thus could benefit from comparison to other streams of students. Second, this study was from regular students, so there is a chance to do the study with non-regular or vocational learners. For future studies, the model could be modified by adding more constructs and moderating variables like system quality, trust, and other technological updates. Finally, this study used a self-reported questionnaire as a research tool, but more future interviews will be strongly recommended for the qualitative analysis and true opinions so that the problem can be handled cautiously when interpreting research data.

\section{CONCLUSION}

This study developed a theoretical integrated model to explain the determinates of science undergraduates' behaviour and actual use of technology towards digital learning during the sudden outburst of online shifting because of the pandemic. A conceptual model was built based on the UTAUT model in order to extend this adequately validated framework by incorporating the following constructs: PP, EE, SI, FC, and BIUT. The data was collected by 425 participants using digital learning. The revealed theta model had high internal consistency, reliability, and validity, which was analyzed by SmartPLS (SEM) software. The study revealed that the positive influence of PE, EE, and SI on BIUT, only the facilitating conditions 
were not associated, as they depended on the individual's background. The findings of the present study could be of value for decision makers in educational institutions.

\section{ACKNOWLEDGEMENT}

Expressed my gratitude to Dr. Fr. John P J Principal, The Bhopal School of Social Sciences(BSSS) College for his constant support and guidance.

\section{REFERENCES}

Ajzen, I. (1985). From Intentions to Actions: A Theory of Planned Behavior. In Action Control. https://doi.org/10.1007/978-3-642-69746-3_2

Alblooshi, S., \& Abdul Hamid, N.A.B. (2021). The Role of Unified Theory of Acceptance and Use of Technology in E-Learning Adoption in Higher Education Institutions in the UAE. IBIMA Business Review. https://doi.org/10.5171/2021.730690

Davis, F.D. (1993). User acceptance of information technology: System characteristics, user perceptions and behavioral impacts. International Journal of Man-Machine Studies, 38(3). https://doi.org/10.1006/imms.1993.1022

Fishbein, M., \& Ajzen, I. (1975). Strategies of Change: Active Participation. In Belief, attitude, intention, and behavior: An introduction to theory and research.

Ganotice, F.A., \& King, R.B. (2014). Social Influences on Students' Academic Engagement and Science Achievement. Psychological Studies, 59(1). https://doi.org/10.1007/s12646-013-0215-9

Hair, J.F., Jr., Matthews, L.M., Matthews, R.L., \& Sarstedt, M. (2017). PLS-SEM or CB-SEM: Updated guidelines on which method to use. International Journal of Multivariate Data Analysis, 1(2). https://doi.org/10.1504/ijmda.2017.087624

Kalule, S.W., Sseguya, H., Ongeng, D., \& Karubanga, G. (2019). Facilitating conditions for farmer learning behaviour in the student-to-farmer university outreach. Journal of Agricultural Education and Extension, 25(3). https://doi.org/10.1080/1389224X.2019.1604389

Momani, A.M. (2020). The Unified Theory of Acceptance and Use of Technology. International Journal of Sociotechnology and Knowledge Development, 12(3). https://doi.org/10.4018/ijskd.2020070105

Scherer, R., Siddiq, F., \& Tondeur, J. (2019). The technology acceptance model (TAM): A meta-analytic structural equation modeling approach to explaining teachers' adoption of digital technology in education. Computers and Education, 128. https://doi.org/10.1016/j.compedu.2018.09.009

Venkatesh, V, Morris, M., Davis, G., \& Davis, F. (2003). Technology Acceptance Model - Research. MIS Quarterly.

Venkatesh, V., Thong, J., \& Xu, X. (2016). Unified Theory of Acceptance and Use of Technology: A Synthesis and the Road Ahead. Journal of the Association for Information Systems, 17(5). https://doi.org/10.17705/1jais.00428 